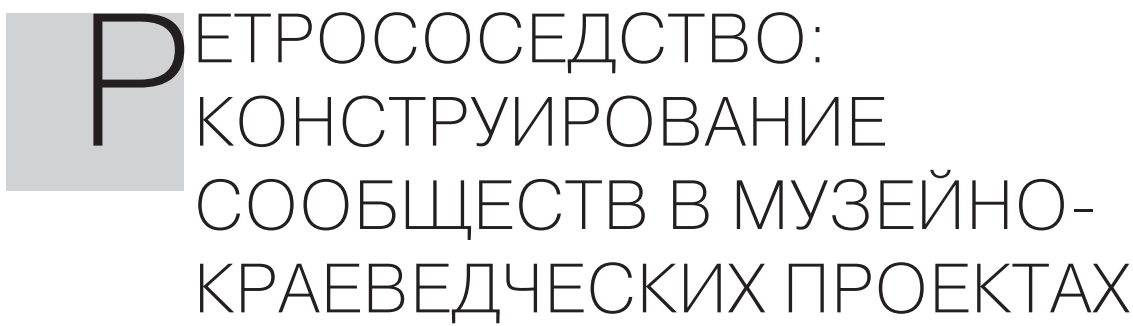

\title{
Павел Куприянов
}

Павел Куприянов, Институт этнологии и антропологии РАН. Адрес для переписки: ИЭА РАН, Ленинский проспект, 32а, Москва, 119334, Россия. kuprianov-ps@yandex.ru.

Исследование выполнено в рамках проекта РНФ № 19-78-10076.

\begin{abstract}
Эссе посвящено описанию ретро(спективного) соседства - специфического типа локального сообщества, конструируемого в современных музейно-краеведческих проектах. Этим термином автор предлагает обозначать такие сообщества, которые, в отличие от обычного соседства, основаны не на рутинных бытовых практиках и межличностной коммуникации, а на памяти и особой привязанности к месту. В статье обсуждаются принципы и механизмы производства такого рода сообществ в двух музейных проектах, реализуемых в Москве с 2017 года: «Басмания. Музей Басманного района» и соседские программы музея «Огни Москвы» («Армянский переулок. Соседи» и «Вместе с соседями»). Специфические модели соседства рассматриваются в перспективе общей для обоих проектов установки на синхронное совмещение краеведческого и социального компонентов. Из разных форм и способов такого совмещения, используемых в практике исследуемых проектов, особое внимание автор уделяет тем, в которых краеведческое содержание облекается в форму повседневной соседской практики. Проведенный анализ позволяет выделить ключевые концепты и специфические особенности изучаемых моделей соседства. Исследование основано на данных включенного и невключенного наблюдения 2017-2020 годов, нескольких интервью и ряде других материалов, в том числе публикациях на сайтах и страницах проектов в соцсетях.
\end{abstract}

Ключевые слова: соседство; память; локальное сообщество; краеведение; музей

\section{ФИГУРА УМОЛЧАНИЯ?}

Тот, кому относительно недавно - скажем, два или три года назад - доводилось прогуливаться по московским переулкам в районе Мясницкой и Покровки, не мог не обратить внимания на небольшие желто-белые стенды, расположенные на домах, заборах, столбах и деревьях (рис. 1, 2). Приятный дизайн и черно-белые фотографии заставляли подойти поближе, чтобы разглядеть детали и прочитать текст. Вблизи становилось понятно, что это не что иное, как уличная выставка, организованная местным музеем «0гни Москвы» в рамках проекта «Армянский переулок. Соседи». Она рассказывала прохожим о «наших соседях» - именно так был озаглавлен каждый стенд. В одних случаях речь шла о конкретном человеке 
или нескольких людях: «Наш сосед философ Николай Бердяев», «Наш сосед Николай Иванович Гучков», «Наши соседи молодые писатели». В других - о повседневных занятиях местных жителей: «Наш сосед идет за хлебом», «Наш сосед “охотится" за Битлами», «Наши соседи снимаются в кино». Сами тексты состояли преимущественно из коротких фрагментов воспоминаний, писем, художественных произведений и справочной информации о месте или человеке. Помимо текстов и фотографий, на каждом стенде был приведен адрес дома, о котором шла речь, а также указаны ближайшие достопримечательности.
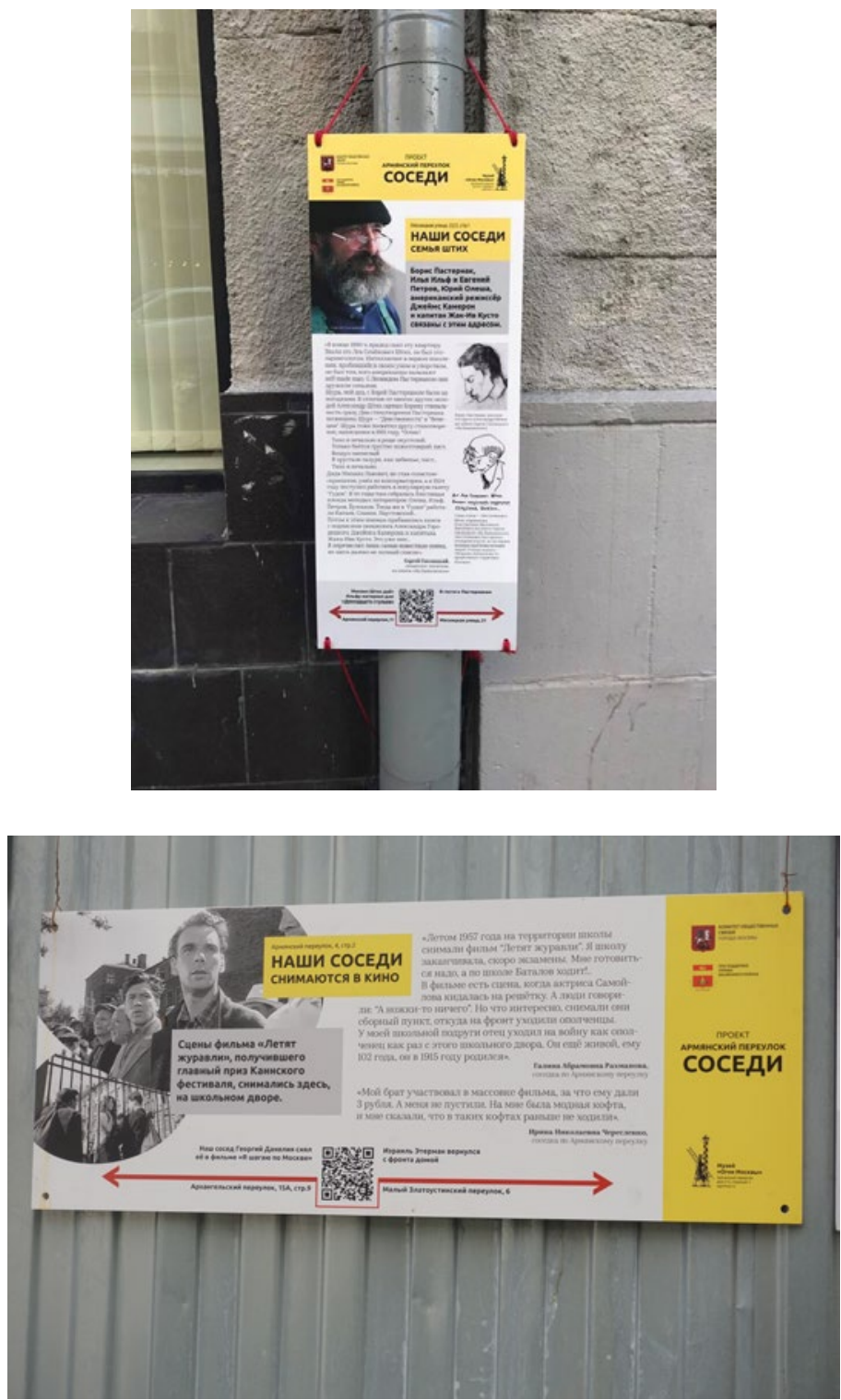

Рис. 1, 2. Стенды с уличной выставки «Соседи» 
В целом, на мой взгляд (и как обывателя, и как исследователя), эта выставка была вполне удачным примером «краеведческой интервенции»в городское пространство: содержательным - но не громоздким, заметным - но не агрессивным. Перемещаясь от стенда к стенду, любопытствующий зритель мог узнать много нового о месте и связанных с ним людях. Благодаря интересным сюжетам, доходчивому изложению и необычной подаче материала выставка пользовалась заслуженным вниманием (особенно вначале). Оказываясь в этом районе, было занятно обнаруживать в новых местах новые стенды, интересно рассматривать старые фотографии и приятно читать воспоминания.

Вместе с тем последовательный осмотр уличной экспозиции давал понять, что сама идея выставки как некоего текста о соседях строится на очевидной (хотя, возможно, и не сразу бросающейся в глаза) фигуре умолчания. Она заключается в том, что речь в этом тексте идет исключительно о прошлом: о людях, которые здесь жили раньше, и практиках, которые были среди них распространены несколько десятилетий назад. Выставка рассказывает о месте и его жителях, но только в одном - историческом - аспекте. Ни из одного текста этой сотни стендов невозможно узнать что-либо о нынешних «соседях» (людях или организациях) и их занятиях. Сам по себе такой исторический ракурс вполне легитимен и как раз очень органичен для краеведческого дискурса, но характерно, что в данном случае он реализуется «по умолчанию» и нигде никак не оговаривается: все герои выставки именуются просто «нашими соседями», как если бы это понятие было хронологически индифферентно и не подразумевало никакой соотнесенности со временем высказывания.

Надо заметить, что то же самое (такое же неожиданное и имплицитное «замещение» настоящего прошлым) относится и к другим мероприятиям этого музейного проекта: на фестивале-конкурсе дворовых игр ${ }^{1}$ нельзя поиграть в современные игры, во время квеста «В гости к соседям»² нельзя попасть в гости к современным соседям, а во время лекций и экскурсий ${ }^{3}$ мало что можно узнать о нынешних обитателях Армянского переулка и окрестностей. Очевидно, это умолчание ${ }^{4}$ носит системный характер и обусловлено самой концепцией проекта.

1 Natalia Potapova, «Приглашаем всех 19 мая в 14.00 на Фестиваль дворовых игр, который состоится в Милютинском саду (Покровский бульвар, 10, территория возле спортивной площадки)», группа в Facebook «Армянский переулок. Соседи». 18 мая 2018 г., https://www.facebook.com/groups/1875605022687103/posts/2056071114640492.

2 Уличный квест «В гости к соседям», страница музея «0гни Москвы» в Facebook, https://www.facebook.com/events/2041695272818912/?active_tab=about.

3 Например, уличные экскурсии «Соседи» (см.: https://www.facebook.com/events /1879269182159447), а также музейные вечера из цикла «Наши соседи»: «Наши соседи - творческие люди» (https://www.facebook.com/events/1834291633559397), «Наш сосед идет в школу» (https://www.facebook.com/events/127825584610422/?active_tab=about) и другие.

4 Разумеется, в анонсах мероприятий обычно сообщается об их содержании. Речь не о том, что организаторы вводят аудиторию в заблуждение, а о том, что этот важный смысловой акцент (на прошлом) никак не оговаривается в названии и как будто подразумевается по умолчанию. 
«Соседский» проект частного музея «0гни Москвы» осуществлялся в 20162018 годах при поддержке Комитета общественных связей Правительства Москвы сначала в качестве программы «Армянский переулок. Соседи», а затем - «Вместе с соседями». В рамках проекта предусматривалось два основных вида деятельности: 1) сбор устных воспоминаний и архивных материалов по местной истории среди жителей Армянского переулка (места расположения музея) и окрестностей; и 2) регулярное проведение культурно-образовательных мероприятий, в том числе с использованием собранных материалов.

Программа мероприятий была довольно насыщенной и включала не только уличные экскурсии, но и тематические лекции, квесты, фестивали, акции, спектакли, выставки и вечера с участием бывших жителей района. Все они были посвящены исключительно темам и сюжетам, связанным с локальной историей: людям, событиям, местам, повседневной жизни района в советское время - словом, по содержанию это был историко-краеведческий проект, направленный на изучение, сохранение и пропаганду местного прошлого. В то же время его ключевой категорией было «соседство» - это понятие не просто фигурировало в названиях обеих программ, но активно использовалось в большинстве мероприятий, что подчеркивало их социальную направленность. Как бы то ни было, по мере знакомства с этим проектом у меня все больше складывалось впечатление, что здесь узнаваемый (и качественный) краеведческий «продукт» почему-то предлагается в неожиданной «соседской упаковке»; что это - историко-краеведческий проект, который по какой-то причине настойчиво и умышленно принимает форму социального.

Еще одним примером подобного совмещения может служить московский проект «Басмания. Музей Басманного района» ${ }^{5}$. 0н реализуется с 2016 года при поддержке разных фондов на базе региональной общественной организации «Слобода» и имеет более широкий масштаб, чем вышеупомянутые программы «0гней Москвы» - и по охвату территории, и по своим целям и задачам. 0н нацелен на продвижение идеи о Басманном районе Москвы как музее под открытым небом, экспонатами которого являются не только привычные дома, памятники и события, здесь происходившие, но и культурные проекты района, туристические маршруты и истории местных жителей, собирание которых является важным направлением деятельности. Проект репрезентируется как создаваемый для местных жителей и силами местных жителей, одним из его основных направлений является работа по развитию локального сообщества и формированию локальной самоидентификации местных жителей, он претендует на роль координатора и центра локальной активности (интервью 1; полевой дневник, 26 января 2018 г.). Вместе с тем главной целью развития локального сообщества (и одновременно основным его средством) является «сохранение и поддержание уникальной историко-культурной среды района» ${ }^{6}$. Таким образом, основным полем заявленной

\footnotetext{
${ }^{5}$ Сайт проекта «Басмания. Музей Басманного района»: https://basmania.ru.

6 Берникова Анна и Ольга Пичугина, «Проект “Басманный. Музей и его жители”. Опыт работы с коллективной памятью местного сообщества» (презентация), 2018, https://drive.google.com/file/d/1LLUmG4P1ZxUiLBsmXlajtE-KSKiJktc/view.
} 
локальной мобилизации в рамках данного проекта вновь оказывается местная история и культура.

Эта культурно-историческая ориентированность обоих проектов неслучайна: и Басманный район (в большей своей части), и входящий в него Армянский переулок с окрестностями расположены в центре города, отличаются исторической застройкой с множеством памятников и мемориальных мест, связанных с известными людьми, и в значительной степени воплощают образ «старой Москвы» с приписываемыми ему особой городской средой и атмосферой. При этом если Басманный район занимает обширную территорию, в том числе за пределами «исторической» части города, и является довольно густонаселенным, то пространство вокруг Армянского переулка и Чистых прудов в настоящее время остается жилым лишь отчасти, становясь все более офисным и рекреационным.

Так или иначе, в обоих случаях мы имеем дело с культурными инициативами, которые, с одной стороны, являются социальными («про соседство/сообщество»), а с другой - краеведческими («про историю/наследие») 7 . Замечу, что это совмещение двух разных компонентов может быть описано по меньшей мере в двух разных ракурсах: и как подстраивание краеведческого под социальное, и как особая форма социальности; иначе говоря, здесь можно увидеть не только попытку краеведческих проектов (пред)стать социальными, но и проявление новой специфической модели соседства, определенным образом связанной с отношением к местному прошлому.

Именно этот последний ракурс является определяющим для данного эссе. Поэтому, оставляя в стороне вопросы о причинах и целях отмеченного альянса, о его прагматике и механике, контекстах и эффектах, я сосредоточусь на описании порожденной им модели соседства - ее отличительных особенностей и форм функционирования. Основным материалом для этого послужат наблюдения за деятельностью обоих проектов в течение 2017-2019 годов. За это время мне довелось принять участие в паре десятков мероприятий разного масштаба и характера в качестве зрителя и участника с разной степенью включенности. Среди них были музейные вечера «Вместе с соседями», «соседские встречи» в музее «Огни Москвы», уличные экскурсии и квесты в рамках обоих проектов, уличный праздник «Веселые соседи, добрые друзья», уличный спектакль «Молоко», презентации, конференции, семинары, выставки и мероприятия выставочной культурной программы. Кроме того, специально по заказу «Музея Басманного района» я исследовал представления жителей о районе, его структуре, границах, социальных и культурных особенностях, благодаря чему не только получил информацию по указанной теме, но и имел возможность участвовать в работе проекта изнутри. Помимо наблюдений, эмпирическую базу исследования составили интервью с организаторами и участниками проектов (5 интервью), материалы в интернете (сайты и сетевые сообщества проектов), печатная продукция, фотографии и видеозаписи.

7 Предпринимаемое здесь разделение краеведческого и социального носит не концептуальный, а инструментальный характер и представляет условную аналитическую схему, позволяющую описать структуру рассматриваемых проектов. Иначе говоря, я не подвергаю сомнению социальность краеведения, а лишь подчеркиваю его специфичность. 


\section{КРАЕВЕДЕНИЕ ... ПО-СОСЕДСКИ}

Изучение текстов и практик названных проектов показывает, что соединение краеведческого и социального компонентов осуществляется в них разными способами, на разных уровнях и с разной степенью успешности. При первом приближении можно выделить две тактики такого соединения. В одном случае социальная (соседская, обыденная, житейская) составляющая включаются в краеведческую рамку: самым очевидным и распространенным примером здесь могут служить уличные экскурсии с использованием воспоминаний местных жителей и специальным вниманием к теме повседневности. Другая же тактика состоит в том, что, наоборот, краеведческое содержание облекается в форму повседневной соседской практики. Для наших целей именно этот вариант представляет наибольший интерес.

В частности, такая схема реализуется в проекте «Басманные посиделки». Как гласит описание, он «направлен на воссоздание традиции "ходить в гости" и культуры “кухонных посиделок"»". В ходе проекта состоялось пять таких «походов в гости» к жителям района, сопровождавшихся видеосъемкой, на основе которой были созданы документальные фильмы. «Сегодня мы отправляемся к жителю Басманного района в гости, и он будет для нас готовить», - говорится в анонсе этого цикла ${ }^{9}$, и далее все происходит именно так, но лишь с одним существенным уточнением: все пятеро жителей оказываются местными краеведами. Судя по фильмам, во время встреч затрагиваются разные темы, в том числе биографическая и, разумеется, кулинарная, однако главной, конечно, остается местная история. По задумке этот проект, очевидно, является очередной попыткой творчески связать историю с современностью, но фактически «кухонные посиделки» оказываются лишь оригинальным форматом презентации краеведческой информации, и ироничное обозначение героев проекта как «шеф-краеведов» ${ }^{10}$, как кажется, отражает искусственность этого совмещения.

Другой выразительный пример - выставка «Музей Басманного района», проходившая в Центре творческих индустрий «Фабрика» в сентябре 2018 года. Выставка была небольшой и кратковременной, но содержательной и запоминающейся. Оформленная в свободном демократичном стиле, она напоминала скорее современное творческое пространство, чем классическую музейную экспозицию11. Здесь были экспонаты разного типа, в том числе интерактивные, от семейных фотографий и личных вещей до пластилиновых скульптур и видеоинсталляций. Выставка сопровождалась насыщенной культурной программой: в первые две недели мероприятия происходили едва ли не через день. Наконец, она была выстроена в соответствии с определенной концепцией, в основе которой лежала

8 См. соответствующий раздел «Басманные посиделки» на сайте проекта «Басмания. Музей Басманного района»: https://basmania.ru/basmannye-posidelki.

9 «Инга Лев приглашает на Басманные посиделки», Музей Басманного района Басмания, загружено 14 сентября 2019 г., видео, .0:30, https://www.youtube.com/watch?v=p3AT8wP1Ce0.

${ }_{10}$ См.: https://basmania.ru/basmannye-posidelki.

11 «Музей Басманного района», Музей Басманного района Басмания, загружено 9 октября 2018 г., видео, 2:29, https://www.youtube.com/watch?v=ZJkL-LmV6lM. 
метафора жилого пространства (дома и двора). С ее помощью осмыслялось и пространство района, и сама экспозиция. «Наш район как один большой уютный дом: улицы и переулки - коридоры», - это высказывание одной из местных жительниц, по словам куратора, подсказало основную идею выставки: «Экспозиция предполагает взгляд на район как на родное и близкое пространство, соразмерное человеку. Как на открытый дом-музей, но жизнь в котором никогда не останавливалась. Как на место, где богатая история органично сплетается с современностью» (полевой дневник, 12 сентября 2018 г.). Уже в этих первых фразах вместе с важным тезисом о человекоразмерности пространства упоминаются значимые оппозиции: прошлое vs. настоящее, музей vs. жизнь. Выставка, как и весь проект в целом, мыслится как пространство непротиворечивого соединения этих противоположностей ${ }^{12}$ : «"Музей Басманного района" - это проект о жизни человека в Москве» (полевой дневник, 12 сентября 2018 г.; курсив добавлен).

Образ музея как жилого пространства находит непосредственное выражение в структуре экспозиции, выступающей в качестве его своеобразной модели и состоящей из трех зон: «двора», «подъезда» и «квартиры-гостиной». Это деление закрепляется в выставочном буклете в лаконичных презентациях каждой зоны, удачно акцентирующих значимые позиции: соседство, совмещение дома (подъезда) и музея, собирательность образа:

Милый двор! Место, где прошло наше детство. Жители района всегда начинают свой рассказ о родных местах с двора, вспоминают добрых (и не очень) старушек, харизматичных дворников, укромные уголки, где так здорово прятаться! Во дворе мы общаемся, узнаем соседей...

«Дом образцового содержания» - это чистый подъезд, прохлада, цветы на подоконниках, приятный запах спокойного камня и оладушек, которые жарит соседка со второго этажа. Мы знаем, как жители района заботятся о своих домах и подъездах. У некоторых там настоящий музей!..

Квартира - настоящий клад для исследователя жизни горожан. Побывать в московской квартире - прикоснуться к скрытому, спрятанному городу. Мы бывали в гостях у многих жителей Басманного района и создали собирательный образ гостиной как одного из центров квартиры ${ }^{13}$.

В каждой зоне посетителям предлагается совершить соответствующие действия: почитать «доску объявлений», оставить послание на стене «подъезда» или в почтовом ящике, наконец, зайти в «гостиную», где «расположиться в кресле или на диване, чувствовать себя дома» ${ }^{14}$. Словом, структура экспозиции воспроизводит некое повседневное пространство условно-обобщенного Басманного двора/ дома, создает определенную игровую рамку для известных обыденных практик и

12 Характерно название одного из проектов: «Басманный район. Музей и его жители», отталкивающееся от этой «смертельной» семантики музея.

13 Музей Басманного района, Центр творческих индустрий «Фабрика», 2018, буклет выставки.

14 Музей Басманного района, Центр творческих индустрий «Фабрика», 2018, буклет выставки. 
соседской коммуникации. Здесь ожидаешь увидеть знакомые бытовые картины и услышать обсуждение реновации, работы ГБУ «Жилищник», «Ямы» на Покровских воротах, магазинных скидок, парковки и других тем, волнующих жителей района.

Тем не менее эти ожидания не оправдываются: как и в других упоминавшихся случаях, содержание предлагаемой рамки оказывается заметно у́же повседневно-соседской тематики и ограничивается одной темой - темой местной памяти, культуры, наследия. С ней так или иначе связаны все экспонаты выставки. Экспонируемые предметы и фотографии из личных коллекций представляют собой преимущественно мемории - «вещи с историей», отсылающие к прошлому семьи, дома, района. «Доска объявлений» целиком состоит из постеров-«визиток» местных культурных учреждений (а, например, не хозяйственных магазинов, сервисных центров или детских площадок). Анонсированные в аннотации рассказы жителей «о родных местах и о себе» оказываются по большей части воспоминаниями. Картины и скетчи изображают главным образом исторические здания (в том числе исчезающие), ювелирные украшения воспроизводят архитектурные детали местных домов, а миниатюрные пластилиновые модели (Красных ворот или коммунальной квартиры) вкупе с советскими уличными табличками, магазинными объявлениями и почтовыми ящиками воспроизводят (или просто обозначают) ушедшую натуру. Все это создает узнаваемую ностальгическую атмосферу, которая дополняется еще одним важным мотивом - исчезающего и нуждающегося в защите историко-культурного наследия. Неслучайно аннотация к выставке (начинавшаяся, как мы помним, с образа уютного дома) завершается пассажем о необходимости сохранения окружающей архитектуры: «Можно и нужно стать камню такой же опорой, какой он является для нас. Беречь его. Защищать. Ценить. Любить» (полевой дневник, 12 сентября 2018 г.).
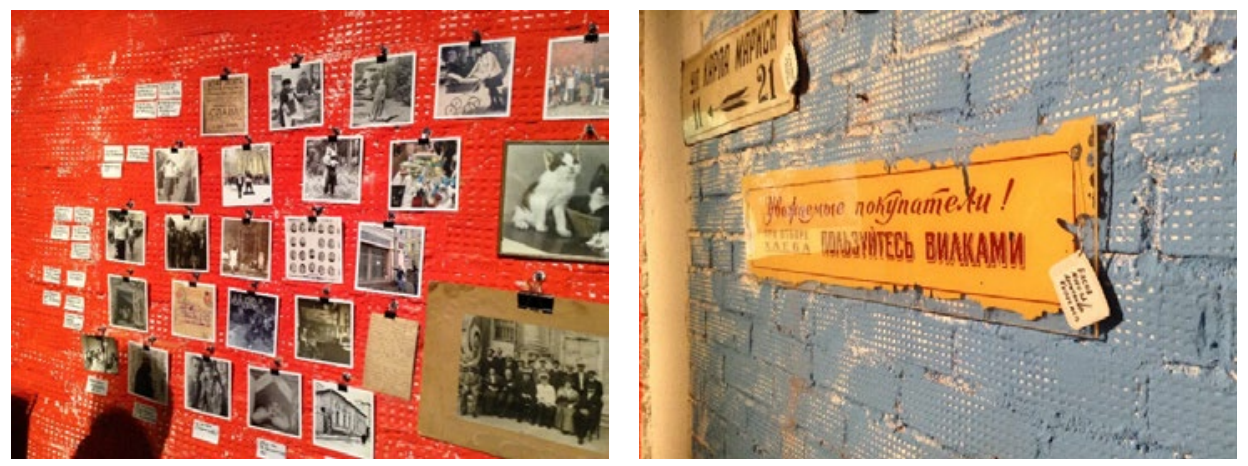

Рис. 3, 4. На выставке «Музей Басманного района»

Закономерно, что и культурно-лекционная программа выставки в значительной мере была обусловлена этим императивом. Здесь были и лекции о выдающихся культурных деятелях, живших на территории района (в частности, о художниках Васнецовых), и рассказы о современной практике работы с наследием (например, о популярном краеведческом проекте Hidden Moscow), и мастерская по изучению семейных архивов. И главная цель всех этих мероприятий заключалась не в том, 
чтобы просто развлечь или проинформировать посетителей, а именно в том, чтобы привить им интерес и любовь к окружающему пространству, научить замечать и ценить его - иначе говоря, сформировать особую, краеведческую, оптику. Эта цель была эксплицирована в броском названии одного из воркшопов - «Разбуди внутреннего краеведа!», - состоявшего из нескольких выступлений представителей «Архнадзора» и «Школы наследия», которые обсуждали, помимо прочего, какие условия и обстоятельства необходимы для того, чтобы «простой» житель стал краеведом.

Сама по себе такая задача полностью соответствует идеологии выставки, где житейское и краеведческое не просто присутствуют рядом друг с другом, а вновь и вновь настойчиво соединяются. «Музей» всегда упоминается рядом с «домом», «жители» - с «памятью», «соседи»- с «наследием», в результате чего создается впечатление, что данные категории тесно связаны между собой и составляют некоторое непротиворечивое единство. Эта установка присутствует не только в общем замысле экспозиции, но и в частных элементах. Например, в обращенном к посетителям предложении опустить в почтовые ящики «рассказ о районе или послание соседу»: при том, что это вообще-то довольно разные жанры, требующие, так сказать, разных «ящиков», здесь они фигурируют как тексты одного порядка и в некотором смысле приравниваются друг к другу. В логике и пространстве выставки (а следовательно - и всего проекта) послание соседу и есть рассказ о районе, поскольку единственной темой соседской коммуникации в этом жилом музее является само место. Жить в этом пространстве означает любить его, ценить его прошлое, хранить память и оберегать наследие. Следовательно, местный житель это тот, кто в той или иной мере привержен данным практикам. Такое понимание не раз проговаривается в текстах проекта, приписывающих жителям особый локальный патриотизм:

Басманный район - настоящий музей под открытым небом, где все дышит историей. [...] Здесь живут неравнодушные люди, которых объединяет любовь к району! (полевой дневник, 21 ноября 2018 г.).

Жители Басманного - патриоты. Они знают множество историй про любимые места района и рады их рассказать любознательным исследователям. Эти истории являются важной частью коллекции музея под открытым небом (Пичугина 2018:4).

Вместе с тем едва ли будет ошибкой сказать, что в этих торжественных формулировках заключена некоторая доля лукавства: они как будто бы относятся к генеральной совокупности, тогда как на самом деле речь идет о выборке, то есть не обо всех жителях Басманного района, а только о тех, которые... Возникающая здесь полисемия делает неочевидным различение «узкого» и «широкого» значения слов «жители» или «соседи», что нередко используется (осознанно или неосознанно) в рассматриваемых проектах - как, например, в процитированных фрагментах или при апелляции к мнению жителей/соседей по тому или иному вопросу (полевой дневник, 28 апреля 2018 г.): то, что воспринимается как относя- 
щееся ко всем жителям и соседям, на самом деле касается лишь определенной их категории.

В связи с этим показателен следующий фрагмент интервью, где напрямую эксплицирован фильтрующий механизм, позволяющий выбрать героев будущего фильма, отделив одних жителей от других:

Информант: Мы выберем от семи до десяти историй жителей, которые какимто образом... биографии связаны с Покровкой и ее окрестностями...

Интервьюер: Живых?

Инф.: Живых. И они просто расскажут свою личную историю. Но... это жители - не просто жители, но они какую-то активную занимают позицию... То есть мы, вот, выбираем как раз тех людей, которые могут что-то рассказать еще о своем районе, о том, как они там вовлекают кого-нибудь, или... что они думают - как нужно спасать район там, или, там, его просвещать... ну и так далее... (Интервью 1).

\section{РЕТРОСОСЕДСТВО: МОДЕЛИ И КАТЕГОРИИ}

Итак, трактовка понятия «жители», которая заложена в концепции проекта и выражена, в частности, в материалах выставки, подразумевает и соответствующее понимание соседства, весьма отличное от общепринятого. Во-первых, сам принцип отбора, выборки из множества, вступает в некую противоречивую перекличку с расхожей народной мудростью, гласящей, что «соседей не выбирают» ${ }^{15}$. А вовторых, упомянутые выше «не просто жители», соответствующие известным критериям, очевидно, формируют особенное (не просто) соседство: его члены делятся друг с другом не солью, а воспоминаниями, встречаются не в подъезде или во дворе, а на экскурсии или семинаре по местной истории ${ }^{16}$, и объединяются скорее для сохранения памятника, чем для установки шлагбаума ${ }^{17}$.

15 В свое время принт со словами «Соседей не выбирают» украшал яркие оранжевые футболки участников проекта «Армянский переулок. Соседи». Вне зависимости от того, насколько эта декларация соответствовала концепции и практике проекта, обратим внимание на то, что его авторам (так же, как и создателям «Басмании»), очевидно, важно подчеркнуть открытость и универсальность конструируемой общности, ее соответствие общепринятым принципам соседства.

${ }_{16}$ Как, например, на семинаре «Территориальное согласие. Басманный район», где обсуждались вопросы, связанные исключительно с локальной памятью и наследием: «Как кооперироваться с соседями и совместно изучать свой район? Как сохранять и приумножать коллективную память поколений? Как простой житель интересного дома может раскопать сведения о нем и добиться признания его памятником архитектуры?» («Территориальное согласие. Басманный район». Семинар в Школе наследия», Школа наследия, загружено 26 декабря 2018 г., видео, 1:39:46, https://www.youtube.com/watch?v=daTXDf9QIQ4\&feature=youtu.be\&fbclid=IwAR29czs TBAUgkmLIMTVm03r9zJRRywMjoxq9GuoN5VI2fMser70cLWyG7bU).

17 «0бъединиться, чтобы сохранить!» - таково было название конференции о наследии Басманного района, организованной с участием «Басмании» в ноябре 2018 года. Итоги V конференции «Объединиться, чтобы сохранить» см. на сайте «Басмания. Музей Басманного района»: https://basmania.ru/itogi-conference. 
Нетрудно заметить, что такое сообщество одновременно и у́же, и шире соседства в обычном понимании, поскольку включает, с одной стороны, далеко не всех здесь живущих, а с другой - тех «иноземцев», которые разделяют соответствующее отношение к месту. Факт физического присутствия в пространстве, собственно проживание на данной территории, не является ни необходимым, ни достаточным основанием для этого соседства; строго говоря, оно представляет собой группу единомышленников и как будто бы носит идеологический, а не локальный характер.

Вместе с тем оно все же формируется именно вокруг места, и именно локальность служит не просто обязательным, а основополагающим фактором и источником солидарности данного соседства. Просто это локальность особого рода, продиктованная принципиально иным статусом места: здесь оно служит не условием и обстоятельством соседских практик (как в обычном случае), а их главным объектом (объектом коммуникации, изучения, привязанности и заботы). Таким образом, место в данном случае оказывается не менее значимой категорией, чем память.

Тема наследия и памяти служит центральной точкой сборки и в той модели соседства, которая воспроизводится в проектах музея «0гни Москвы». Об этом красноречиво свидетельствует, например, буклет «Вместе с соседями», посвященный одноименному проекту: судя по содержанию буклета, вместе с соседями можно делать почти исключительно то, что так или иначе связано с изучением, репрезентацией, сохранением местного прошлого ${ }^{18}$. В то же время принципы формирования и структура соседского сообщества здесь иные, отличные от тех, что в «Басмании» (хотя тоже довольно необычные). Вот показательный эпизод из рассказа о соседях:

Есть не [те,] кто здесь вырос или родился, а вот последняя соседка - она пришла в музей... Она раскопала, что ее дед ушел в армию... на Гражданскую войну, в 1918 году, и адрес написан: «Армянский переулок, дом 5». [0на] узнала о проекте, пришла искать, где именно дом 5 - у нас же все дома 3-5 сейчас. Ей интересно [увидеть] тот дом, она говорит: «Мне папа когда-то показывал, [а] я забыла...». То есть она вот сейчас вообще в Англии живет, но они с мамой пришли и там у них... принесли свидетельство о его крещении, что он крещен в церкви Евпла. Вот тоже... как бы они тоже - соседи [смеется] (Интервью 3).

В этой истории важно сразу несколько моментов. Во-первых, из нее становится понятно (и об этом уже шла речь выше), что для того, чтобы быть соседом, вовсе необязательно жить не только в данном районе, но и вообще в России (к слову, таких «заграничных» соседей немало в обоих проектах) - достаточно иметь соответствующую заинтересованность и хотя бы косвенные связи с районом, пусть даже в отдаленном прошлом. Во-вторых, на мой взгляд, смех рассказчицы в конце приведенной цитаты и предположительная частица «как бы» косвенно свидетельствуют об условном характере соседского статуса, приписываемого героине истории. Наконец, еще более примечательным мне представляется возникаю- 
щее здесь хронологическое «расширение» соседства - заметим, довольно неожиданное. Очевидно, соседские связи в рассматриваемой модели соседства распространяются не только в горизонтальной плоскости (синхронии), но и в вертикальной (диахронии):

Информант: А Вы знаете, что мы нашли за ноябрь соседей из нашего дома, две семьи?

Интервьюер: Круто! Поздравляю!

Инф.: Да! И я нашла соседей из своего кабинета!

Инт.: Это Ваши соседи персональные.

Инф.: Да, это мои, персональные. Он рассказывал, как он приходил к своей любимой, которая сейчас его жена, и выпрыгивал из кабинета моего, [из] окна, из ее комнаты, когда туда возвращалась неожиданно мама.

Инт.: Отличная история.

Инф.: Я смеялась: я говорю, я чувствовала, что дух авантюризма у меня в кабинете витает...

(Интервью 3).

Приведенный фрагмент прямо свидетельствует об альтернативном понимании соседства, основанном на вневременных, асинхронных связях с местом. Если «обычное» соседство подразумевает совмещение временно́го и пространственного измерений (этимологически соседи - это «сидящие вместе», то есть в одном месте в одно время), то в данном случае темпоральная привязка отсутствует, и соседи оказываются объединены только пространством. Поэтому если «обычные» соседи живут только рядом друг с другом, то эти могут жить буквально в одном и том же месте (хотя и в разное время). Так появляется фигура «персонального» соседа (из твоей комнаты/кабинета), невозможная в «обычном» соседстве, а также совсем сюрреалистическая сцена, в которой сосед скрывается от будущей тещи, выпрыгивая из окна музейного кабинета. Все это - органичные порождения той асинхронной трактовки соседства, которая лежит в основе проектных выставок и культурно-образовательных мероприятий музея. Она объединяет в одно локальное сообщество Артамона Матвеева, Владимира Шухова, Марину Цветаеву, Луиса Корволана и многих других людей совершенно разных эпох. Все они оказываются друг другу соседями, потому что когда-либо имели отношение к этому месту, а не из-за того, что живут рядом. Иначе говоря, если это и сообщество, то, во-первых, виртуальное, воображаемое (хотя бы в силу того, что большинство его членов, очевидно, не были знакомы друг с другом), а во-вторых, основанное на территориальных, а не социальных связях с местом, а не с людьми.

Заметим, что, как и в предыдущем случае с «Басманией», локальность вновь оказывается центральной категорией, что, очевидно, неслучайно. Концепт места, одинаково необходимый и значимый как для краеведческой, так и для соседской составляющей рассматриваемых проектов, во многом определяет не только их грамматику, но и прагматику: в известном смысле они направлены именно на конструирование, символическое производство места. По крайней мере, это безусловно один из значимых эффектов всей проектной деятельности. 
Уже сама категория соседства указывает на конкретный локус, легитимизирует его существование как определенного (в физическом и семантическом смысле) фрагмента пространства: само понятие «соседи» с очевидностью подразумевает наличие некой общей «своей» территории, ведь сосед всегда мыслится как сосед по чему-то: дому, двору, улице или району. Для рассматриваемых соседских проектов такими пространственными денотатами являются район Чистых прудов и Басманный. В последнем случае вопрос легитимизации особенно актуален по той причине, что Басманный район, вопреки довольно давним и многочисленным усилиям ${ }^{19}$, в восприятии жителей все еще остается преимущественно административной единицей. В этой ситуации целенаправленное, откровенное и неустанное конструирование авторами «Басмании» общерайонной басманной идентичности $^{20}$ (что является одной из целей проекта) несомненно «работает» на место.

Проявлением локальноцентричной оптики можно считать и довольно четко определенную (по крайней мере, на начальном этапе) пространственную привязку проектов:

Мы, когда проект делали, мы сразу уже обозначили границы. Для нас это была, вот, уже понятна граница, мы даже не обсуждали, Это вот Покровка Маросейка, и вот этот Чистый пруд и... с этой стороны - ну, как бы, Лубянский проезд, получается... (Интервью 2).

Изначальная внешняя заданность территориальных границ (пусть и неизбежно корректирующихся в процессе) красноречиво указывает на место как на основополагающую категорию проекта.

\section{ЗАКЛЮЧЕНИЕ}

Исследователи соседских институтов и практик в качестве конституирующего основания локальных сообществ указывают совместное проживание ${ }^{21}$. Таким же очевидным и обязательным это условие является и в обыденном понимании соседства. Между тем модели соседства, воспроизводимые в описанных выше

190 конструировании Басманного района как отдельного места см.: Куприянов 2016.

${ }^{20}$ Следует заметить, что для достижения этой цели используются самые разные способы, более или менее изощренные. К самым незамысловатым можно отнести навязчивое (и зачастую избыточное) повторение названия района и его производных, в том числе неологизма «Басмания», - практически в каждом тексте. К наиболее оригинальным - представленную на выставке «Музей Басманного района» интерактивную схему района, на которую каждый желающий мог наклеить стикеры с указанием своих личных памятных мест, тем самым обозначив и закрепив свою связь с районом сразу в нескольких регистрах: вербальном, визуальном и телесном. Благодаря тому, что схема ограничивалась контурами района, посетителям предлагалось себя вписать именно в пространство района, а не, например, всего города или округа (см. раздел «Карта, которую вы создали сами» на сайте проекта «Басмания. Музей Басманного района»: https://basmania.ru/narodnaya-karta).

${ }^{21}$ Совместность и близость проживания связывается с аморфным периодическим взаимодействием соседей прежде всего для решения хозяйственных вопросов (Ивлева 2010; Шомина 2015). 
проектах, удовлетворяют этому условию лишь частично, поскольку оказываются лишены либо одного компонента (совместного...), либо другого (... проживания $)^{22}$. В первом случае перед нами идейное объединение современников, в котором проживание на территории является необязательным, а во втором - умозрительная совокупность всех местных жителей разных эпох. Стало быть, эти специфические соседства едва ли можно считать полноценными локальными сообществами, поскольку, строго говоря, одно из них не совсем локальное, а другое - совсем не сообщество. При этом между ними есть весьма существенные сходства не только стилистического, но и концептуального характера, что дает основания объединить их в одну общую категорию или тип. Принимая во внимание ретроспективную направленность, разделяемую ценность местного прошлого и сфокусированность на памяти и наследии, его можно было бы обозначить как ретро (спективное) или же - отдавая дань доминирующему концепту места - краеведческое соседство. В нынешних условиях динамично меняющейся социальности этот специфический тип соседства, построенный на замысловатом сплетении двух привязанностей - к месту и к прошлому, очевидно, является востребованной формой проявления локальной идентичности. А сегодняшний всплеск интереса к наследию вкупе с развитием разного рода общественных инициатив и неформальных коопераций позволяет предположить, что в ближайшее время он получит широкое распространение и будет представлен более чем двумя рассмотренными версиями.

\section{СПИСОК ЛИТЕРАТУРЫ}

Ивлева, Ирина. 2010. «Городские соседские сообщества в процессе трансформации». Вестник Санкт-Петербургского государственного университета. Серия 12 «Психология. Социология. Педагогика» (3):339-346.

Куприянов, Павел. 2016. «К вопросу о конструировании мест в современном городе: механизмы и идентичность». Лабиринт. Журнал социально-гуманитарных исследований 5:37-45.

Пичугина, Ольга, ред. 2018. Люди. Улицы. Дома. Рассказы москвичей о Басманном районе. М.: Б. и.

Шомина, Елена. 2015. «Соседские центры как элемент инфраструктуры соседского сообщества». Экономические и социально-гуманитарные исследования 4:95-104.

\section{СПИСОК ПРОЦИТИРОВАННЫХ ИНТЕРВЬЮ}

Интервью 1 - АБ, руководитель проектов «Басмании», 25 декабря 2016 г.

Интервью 2 - ЛГ, сотрудник музея «0гни Москвы», координатор проектов «Армянский переулок. Соседи» и «Вместе с соседями», 17 февраля 2018 г.

Интервью 3 - НП, сотрудник музея «Огни Москвы», руководитель проектов «Армянский переулок. Соседи» и «Вместе с соседями», 27 января 2020 г.

22 По замечанию Елены Шоминой, в последнее время основанием для возникновения соседских объединений все чаще становятся общие интересы, а не совместное проживание (2015:95). Можно сказать, что наши кейсы соответствуют этой тенденции, однако в предлагаемую классификацию соседских сообществ (96) они вписываются с трудом, представляя собой, очевидно, все-таки слишком специфические случаи. 


\section{PETRO-NEIGHBORHOOD: CONSTRUCTING COMMUNITY IN MUSEUM AND LOCAL-HISTORY PROJECTS}

\section{Pavel Kupriyanov}

Pavel Kupriyanov, Institute of Ethnology and Anthropology, Russian Academy of Sciences. Address for correspondence: Institute of Ethnology and Anthropology RAS, Leninskii prospekt, 32a, Moscow, 119334,Russia.kuprianov-ps@yandex.ru.

This study was supported by the Russian Science Foundation, project No. 19-7810076.

The essay is devoted to the description of retro(spective) neighborhood-a specific type of local community, constructed in modern museum and local-history projects. I use this term to refer to communities that, unlike ordinary neighborhoods, are based not on routine everyday practices and interpersonal communications, but on memory and a special attachment to the place. The essay examines the principles and mechanisms of such communities' production in two museum projects implemented in Moscow since 2017: Basmannyi District Museum Basmaniia and the neighborhood programs of the Moscow Lights Museum ("Armenian Lane: Neighbors" and "Together with Neighbors"). I consider specific neighborhood models in the context of common for both projects framework of the synchronous combination of local-history and social components. Of the different forms and methods of these combinations used by the projects I examine, I pay special attention to those where the local history content is framed as everyday neighbor practice. My analysis identifies key concepts and specific features of the studied neighborhood models. This study is based participant and nonparticipant observation conducted in 2017-2020, several interviews, and a number of other materials including museum projects' websites and pages in social networks.

Keywords: Neighborhood; Memory; Local Community; Local History; Museum

\section{REFERENCES}

Ivleva, Irina. 2010. “Gorodskie sosedskie soobshchestva v protsesse transformatsii." Vestnik SanktPeterburgskogo Gosudarstvennogo universiteta, Series 12 Psychology, Sociology, Pedagogy 3:339-346.

Kupriyanov, Pavel. 2016. “K voprosu o konstruirovanii mest v sovremennom gorode: Mekhanizmy i identichnost'." Labirint: Zhurnal sotsial'no-gumanitarnykh issledovanii 5:37-45.

Pichugina, Ol'ga, ed. 2018. Liudi, ulitsy, doma: Rasskazy moskvichei o Basmannom raione. Moscow: N.p.

Shomina, Elena. 2015. "Sosedskie tsentry kak element infrastruktury sosedskogo soobshchestva." Ekonomicheskie i sotsial'no-gumanitarnye issledovaniia 4:95-104. 